\title{
AIRBORNE ASSAULT ON CORREGIDOR: A STUDY IN WEATHER, TERRAIN, AND CULTURAL LANDSCAPES
}

\author{
Andrew D Lohman \\ United States Military Academy, West Point
}

\begin{abstract}
In many ways, military forces using advanced technologies have been able to overcome a number of the inherent and traditional challenges posed by physical geography. However, geography continues to play a significant role in military planning and operations in two areas that have received little attention in the literature, namely airborne operations and the cultural landscape. This case study sought to contribute to these discussions by analysing the American operation to seize Corregidor Island in February 1945. As a primarily airborne assault, the operation was heavily contingent on weather, but also on terrain for sufficient drop zones, and the cultural landscape and terrain intelligence of the American forces proved vital in this regard. Through analysing archival military planning documents, maps, images and other primary and secondary sources, this study found that the physical terrain and enemy defences dictated the overall plan, but two features of the cultural landscape, the parade ground and golf course, were essential to the airborne operation, serving as the smallest drop zones used in World War II by US forces. While these two spaces enabled the assault, their small size, the buildings surrounding them, and the prevailing winds made this mission the most dangerous and highest jump casualty airborne operation of the war. Despite the casualties incurred by these features, the bombed-out buildings and debris on the drop zones arguably prevented even greater casualties because of the cover these provided once paratroopers were assembled on the ground. The intent of this discussion is to demonstrate how airborne operations are inherently contingent on geography and the challenges and opportunities the cultural landscape could pose during a military operation.
\end{abstract}

Key words: military geography, airborne operations, Corregidor, cultural landscape, terrain intelligence.

\section{Introduction}

Cromley's recent article in the Professional Geographer, on French parachute operations in the French Indochina War, brought attention to the fact that in the vast and growing body of military geography literature, little work has been devoted specifically to airborne operations. ${ }^{1}$ This is surprising, as these are inherently dependent 
on geographic factors such as weather, terrain and overcoming the challenges of space and distance through 'vertical envelopment'. Today, modern technology has enabled military forces to overcome, and in many cases nullify, some of the traditional impacts of geography, such as the effects of weather, terrain and climate. Airborne operations, however, remain largely dependent on specific geographic conditions to ensure success. And while strategists are currently debating the future utility and risks of airborne operations, discussions of cultural landscapes and places as symbolic objectives are receiving much greater attention than ever before in news and strategy forums. These debates make the American assault to recapture Corregidor in February 1945 an interesting case study to analyse as each of these factors played a vital role in planning, course, and outcome of the battle.

The intent of this article is not to recount the ebb and flow of the battle itself, as this has been detailed in many excellent works already, but to focus on these three aspects:

- weather as its relates to airborne operations;

- the role of what Doyle and Bennett term "terrain intelligence"; and

- the cultural landscape - the result of human activity to shape and modify the natural environment.

Towards this end, the article first reports on the examination and description of the location and geography of Corregidor, both physical and cultural, as well as the Japanese defensive strategy. These geographies illuminate how and why an airborne assault was the most favourable course of action. The importance of weather and terrain in airborne operations are then discussed, and reveals how Corregidor was far from ideal for such an assault. However, the Americans possessed a tremendous amount of 'terrain intelligence' about the island, which proved vital to the planning and ultimate success of the mission. As is described here, the airborne phase of the assault was only possible due to two unlikely features of the cultural landscape, the parade ground and the golf course. The small size of these spaces as well as the shattered buildings surrounding them, however, made these drop zones the most dangerous in the war and the $503^{\text {rd }}$ Parachute Regiment experienced the highest jump casualties among US airborne forces. Yet, these same features provided invaluable cover to the attacking parachutists once on the ground, and possibly saved many of the paratroopers' lives.

This 1945 battle does not receive a lot of attention in comprehensive works on World War II because it is overshadowed by the larger battles and campaigns fought during that conflict. Yet, there is a great deal written on the subject, including a large number of primary sources in the form of monographs written by American officers attending advanced military education courses following the war. During the course of this research, a tremendous amount of invaluable, historical personal accounts, photos, images and maps were found on the 503d PRCT Heritage Battalion website. ${ }^{2}$ These works, together with official army documents and histories, including preinvasion operations orders and post-operation narratives, and a number of detailed 
secondary historical works show that LTG Flanagan's dedication is extremely apt - "For the valiant soldiers of the Rock Force - paratroopers and amphibians - who overcame great odds of enemy, terrain, and weather to free Corregidor."”3

In most of these works, however, authors discuss and assess terrain along the lines detailed in Duke Winters' Battling the elements, describing the impact and influence of the physical landscape on battles and campaigns. ${ }^{4}$ Yet, closer examination of this battle reveals that while the physical terrain of Corregidor was indeed challenging, arguably the cultural landscape - the physical landscape as modified by human activity - played a crucial role in planning and conducting the 1945 attack to recapture Corregidor Island.

Although this battle was fought over 73 years ago, and much has changed in military equipment, technology, planning and operations, there are a number of relevant lessons for today's military operating environments. It was an inherently joint and well-coordinated operation between the US Army, the Navy and the Army Air Corps, and the assaulting force was essentially the modern equivalent of a brigade combat team. However, the ultimate objective in the current analysis was to demonstrate how geography, and specifically the weather, terrain and cultural landscape, shaped the tactical plan for this assault. In conflicts around the world today, cultural landscapes are arguably playing a larger and more effectual role, yet, geo-historical analyses of past conflicts reveal how important these landscape features have been in the past, and how these analyses could inform our current understanding of their role, or potential role, in conflict.

\section{Corregidor Island}

Bush et al. in their Battlebook case study wrote, "Corregidor is a rocky outcrop of land which would be totally without significance were it not for its location, guarding the entrance to Manila Bay - the largest and most important harbor in the Philippines." In the heyday of expanding empires and coastal defence fortifications to protect these vital locations, Corregidor, the largest of the five islands that sit in the mouth of Manila Bay, assumed a strategic significance (see Figure 1). Flanagan, in discussing Corregidor and the four other islands, noted that the islands were formed, "through a fortunate quirk of nature," but geologists have concluded that they are the remnants of an ancient caldera. ${ }^{7}$ The island divides the entrance to Manila Bay into two channels, the two-mile-wide $(3,2 \mathrm{~km})$ North Channel, and the eight-mile-wide $(12,8 \mathrm{~km})$ South Channel, and provided a crucial forward position from which to defend Manila, approximately 30 miles $(48 \mathrm{~km})$ to the east. ${ }^{8}$ 


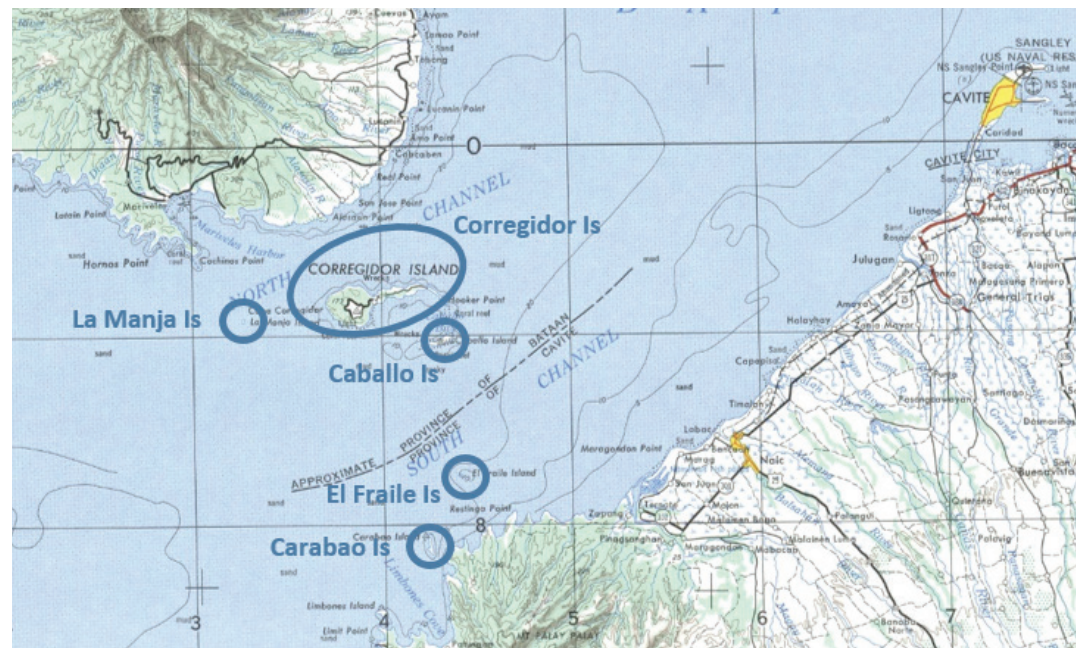

Figure 1: Army Map Service, Corps of Engineers map of Manila, Philippines (dated 1955; scale: 1:250 000) showing the location of Corregidor and four other islands strategically positioned at the entrance to Manila Bay.

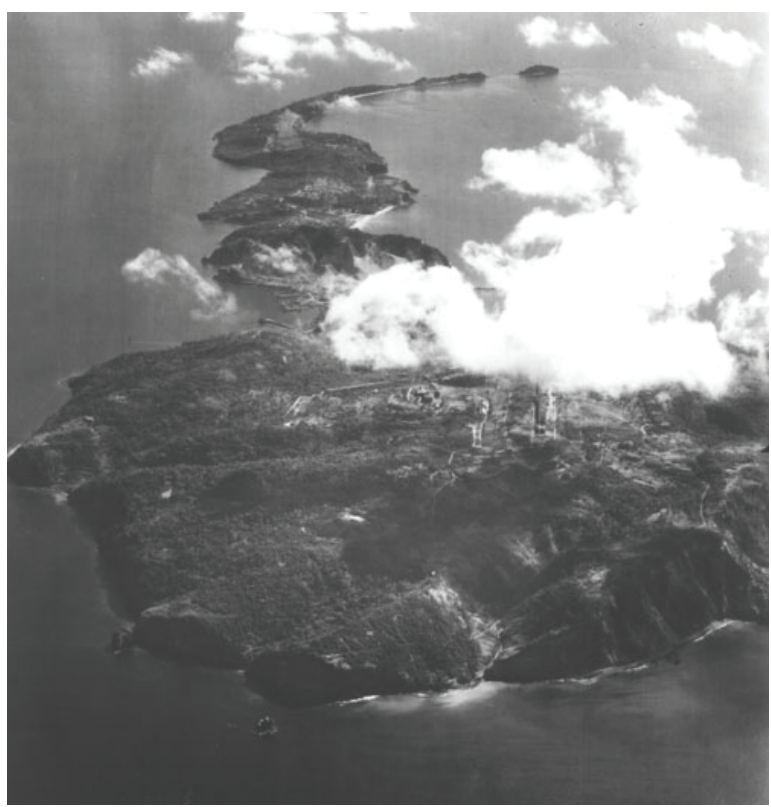

Figure 2: Corregidor Island from the air before American forces landed, February 1945. US Army Photo Courtesy National Archives. ${ }^{9}$ 
Corregidor is often described as a 'tadpole' about 5,6 kilometre-long (3,5 miles), with the westward head of the island approximately 2,4 kilometres (1,5 miles ) at its widest point (see Figures 2 and 3). Most sources list it as approximately 1735 $\operatorname{acres}^{10}$ (2,7 square miles or 7 square kilometres), which is approximately twice the size of modern-day Central Park in New York City. The topography of the island varies greatly, and most analyses divide the island into five segments. The highest section on the island is the plateau dubbed "Topside" by Americans. Its highest point sits approximately 195 metres (640 feet) above sea level, with steep cliffs on the north, west and south sides that drop precipitously to the sea below. Several large, steepsided ravines cut through the cliffs to the narrow beaches on three sides. To the east of Topside, sits another plateau, "Middleside", about 121,9-152,4 metres (400-500 feet) above the sea, with a steep decline down to "Bottomside", described as the 550 metrewide neck (601,5 yards), which sits only a few feet above sea level and connects the head and the tail of the island. ${ }^{11}$ Just east of Bottomside is Malinta Hill, comprising a seam of dacite that rises to approximately 120 metres (390 feet) and descends quickly to the tail, which extends for another 3,2 kilometres ( 2 miles) and gradually narrows to a point. ${ }^{12}$ The western portion of the tail comprises a low ridge with several slight hills, while the eastern half is a slight plateau that is graded to allow construction of Kindley Field, a 914-metre (3 000-foot) airstrip. Because of the nature of the terrain on the tail, it was deemed "the best place for an amphibious landing - it had thousands of yards of traversable beach below fifty foot cliffs". ${ }^{13}$

Corregidor was designated an American Military Reservation in 1902, but a regular Army post was not established there until 1908, and construction of fortifications did not begin until 1909 with the arrival of an engineering unit. ${ }^{15}$ During the next thirteen

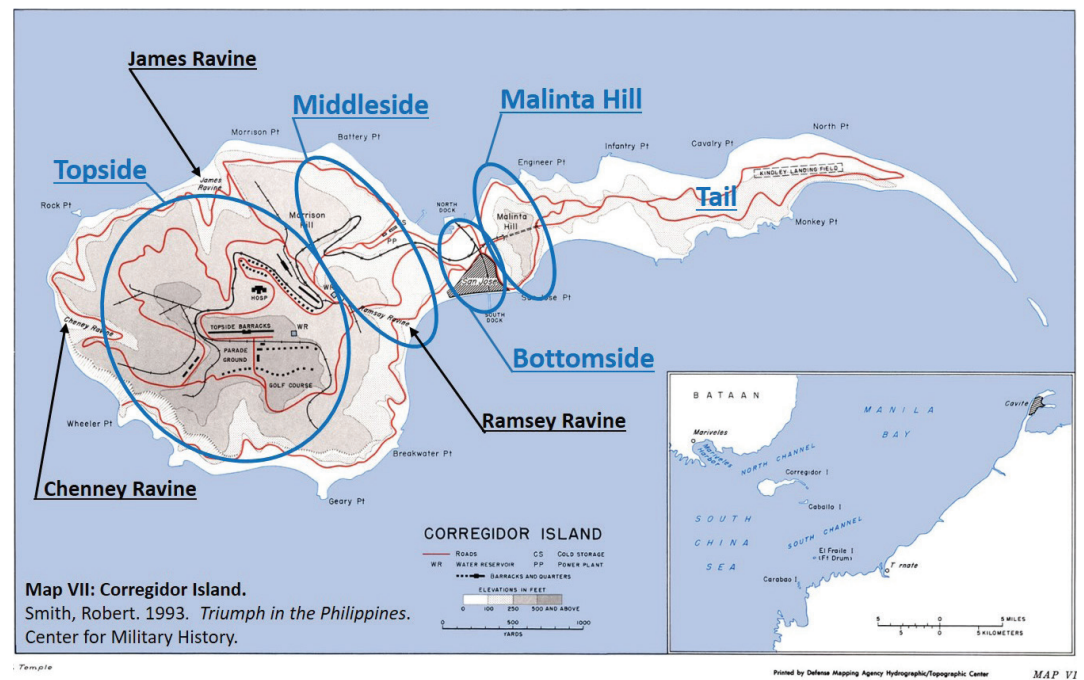

Figure 3: Map of Corregidor depicting many aspects of the cultural and militarised landscape. ${ }^{14}$ 
years, the US Army expended millions of dollars to fortify four of the five islands in Manila Bay, turning Corregidor into a truly militarised landscape. Further efforts to fortify the islands ended in 1922 with the Washington Naval Treaty, which both the US and Japan signed, to curtail a naval arms race in the Pacific. ${ }^{16}$

The landscape of Corregidor was transformed during this process and became known as "The Gibraltar of the East". The focal point of this militarised landscape was the island's 13 batteries composed of 56 12-, 10-, 8-, 6- and 3-inch guns, 12-inch mortars, and $155 \mathrm{~mm}$ guns and artillery pieces that were crucial to the defence of Manila Bay. ${ }^{17}$ Because the expected threat was from the sea, most of these batteries were oriented in that direction. As these fortifications were developed, Corregidor's physical landscape was significantly altered to suit this militarised purpose. During this period, the US Army built over $104 \mathrm{~km}$ (65 miles) of roads, about $24 \mathrm{~km}$ (15 miles) of electric rail, headquarters buildings, barracks, a hospital, mess facilities, a power generation plant, living quarters for officers, non-commissioned officers (NCOs) and soldiers (both Filipino and American), service clubs and storage for the supplies of the garrison as well as housing and schools for American and Filipino dependants. ${ }^{18}$ Most of the families of the Filipino forces were housed in the small barrio of San Jose, at Bottomside on the south shore of the island. Two docks, North and South, were constructed to enable the delivery of supplies to support the garrison. Despite the prevalence of vegetation on the island, there was a lack of fresh water sources. Water was pumped from a series of deep wells on the island, as well as barged to Corregidor from the port of Mariveles on Bataan. Despite the unique shape and structure of the island, military planners organised these spaces into separate officer, NCO, and enlisted soldier housing areas and also added features common to American military bases. The most prominent of these were the parade ground adjacent to the Long Barracks (see Figure 4), believed to be the longest military barracks in the world at the time. They also added a nine-hole golf course to provide recreational opportunities for those stationed on the island. These elements of the cultural landscape proved vital for American forces during this battle.

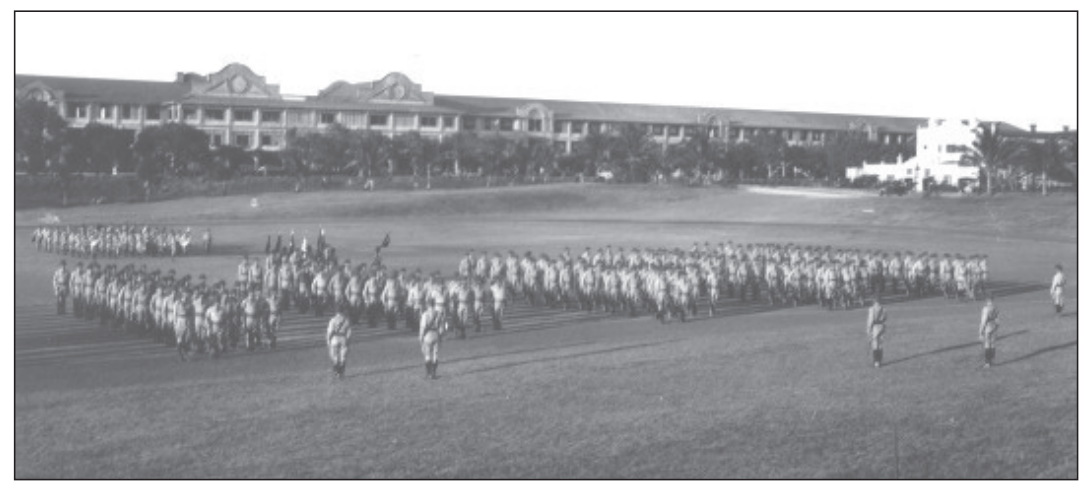

Figure 4: Evening formation on the parade field in front of Topside barracks ${ }^{19}$ 
Although the Washington Naval Treaty prohibited further militarisation of the landscape, the United States. constructed an elaborate tunnel system, the Malinta Tunnel, between 1931 and 1938 to serve as storage space for the garrison's supplies and equipment. ${ }^{20}$ The main east-west tunnel was 426 metres long (1 400 feet) with 24 9-metre-wide (30 foot), 121-metre-long (400 foot) lateral tunnels. It also contained an additional section of 12 laterals for the hospital and as well as one with 11 laterals for use by the quartermaster (see Figure 5). This tunnel system proved to be crucial during the intense, month-long bombardment of the island by the Japanese in 1941 and 1942, providing a significant degree of protection for the Allied garrison, which swelled to almost 15000 before its surrender on 7 May 1942. These tunnels, together, with numerous others, constructed as part of their defensive positions in late 1944 and early 1945, housed significant numbers of Japanese troops during the three-week aerial and naval bombardment prior to the American assault on 16 February 1945.

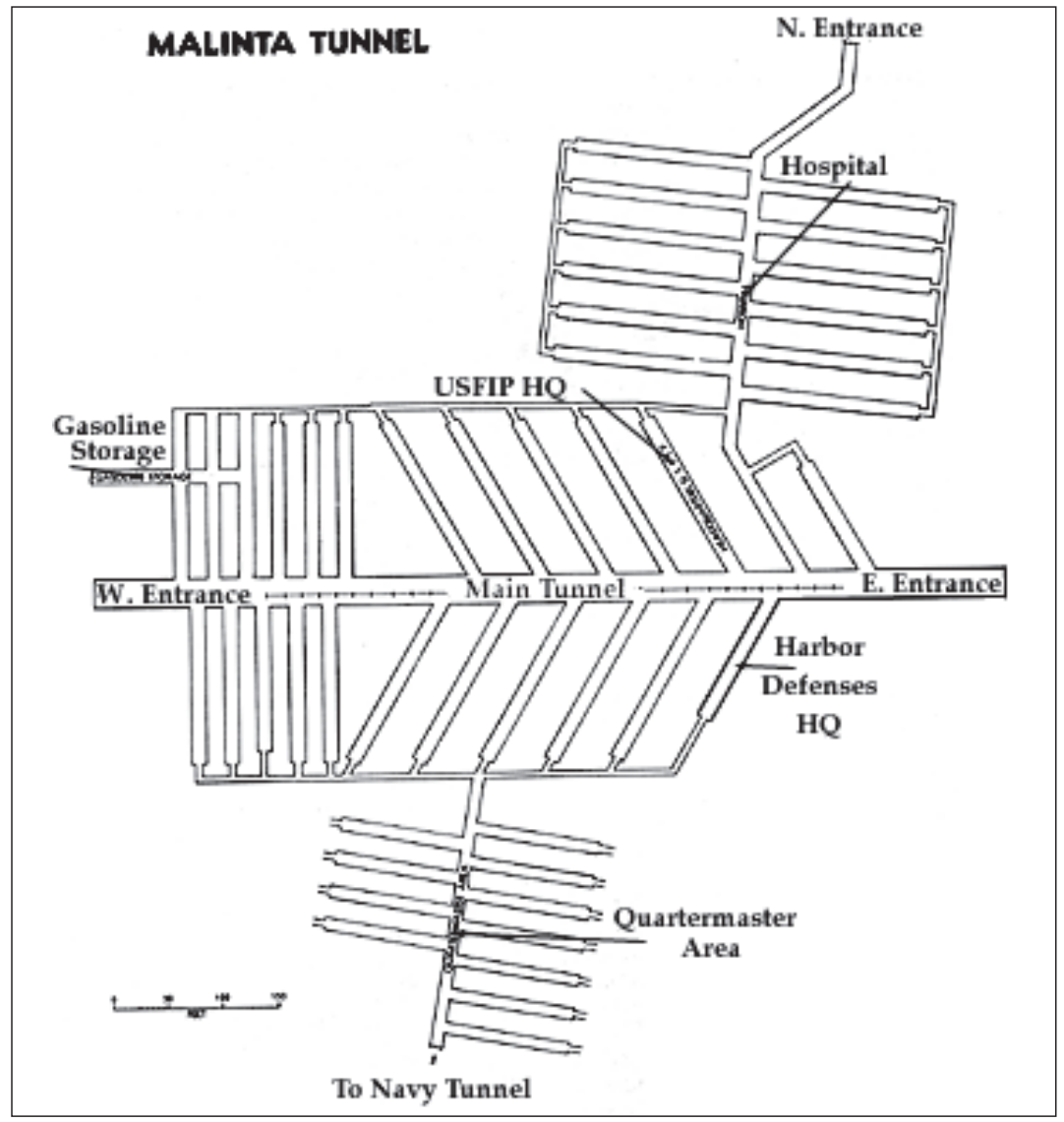

Figure 5: Sketch of the Malinta Tunnel system on Corregidor. 


\section{The plan}

On 9 January 1945, the US Sixth Army landed in Lingayen Gulf, followed shortly by landings south of Manila. By early February, US forces were converging on the city from the north and the south. ${ }^{21}$ However, the Japanese naval forces continued to defend the city and garrisoned Corregidor Island. As described in the official US Army history of the Philippines campaign, "Without Corregidor Island, the Port of Manila after its capture could not be effectively utilized, as coastal guns on the island could hamper our shipping. Too, Corregidor was believed to harbour so-called Japanese suicide 'Q' boats."'22

Hence, the question facing US forces was how to assault Corregidor. Throughout the war, amphibious assaults were the means through which US and Allied forces initiated attacks on islands and coastlines. However, an amphibious assault against Corregidor posed significant challenges and risks. Planners, remembering the high casualty rates the Japanese suffered in their May 1942 landing on the northern coast of Corregidor's tail, anticipated that an American attempt to attack the island from the sea would likely experience significant casualties, particularly as the Japanese leadership on Corregidor deemed this the most likely course of action for US forces. ${ }^{23}$

Despite having been warned by the Japanese high command to be prepared for a potential airborne assault, Captain (Capt.) Akira Itagaki, the Japanese commander on Corregidor, did not plan for a defence against an airborne drop. Rather, he focused his efforts against an amphibious assault, and based on this assumption, he arrayed approximately half his force in positions to defend James, Cheney and Ramsey Ravines and at Malinta Hill (see Figure 3), which controlled access from the beaches to the high ground on Topside or Malinta Hill. Itagaki placed the reserve forces in the Malinta tunnel system. ${ }^{24}$

As Capt. Lester Levine, the regimental adjutant, noted in his monograph, there were ultimately three reasons for preferring an airborne assault:

- the Americans remembered the high Japanese casualties in their assault on the tail of Corregidor in May 1942;

- the Japanese had three years to fortify the island against amphibious assault; and

- the US forces would be forced to make an uphill assault once landed. ${ }^{25}$

Although significantly less than in the European theatre, US commanders in the Pacific employed the $11^{\text {th }}$ Airborne Division and the $503^{\text {rd }}$ Parachute Infantry Regiment in a number of airborne operations in the Southwest Pacific. ${ }^{26}$ Because of anticipated high casualty rates for an amphibious assault, the decision was made to conduct an airborne assault against the island, supported by a smaller amphibious landing. The mission was assigned to the $503^{\text {rd }}$ Parachute Infantry Regiment under the command of Colonel (Col.) George M Jones, and together with the attached $462^{\text {nd }}$ Parachute Field Artillery Battalion, Company C, $161^{\text {st }}$ Airborne Engineer Battalion, and the $3^{\text {rd }}$ Battalion, $34^{\text {th }}$ Infantry Regiment (to conduct the amphibious assault), the 
regimental combat team was dubbed 'The Rock Force'. Once the mission and unit had been assigned, the question of where to drop the paratroopers on the island arose. As it quickly became apparent, Corregidor did not appear to be the ideal location for an airborne assault.

\section{Airborne operations}

Two of the main principles underlying airborne operations during World War II were surprise and mass. ${ }^{27}$ The ability to project potentially large forces anywhere on the battlefield, at any time, unhindered by the constraints of ground or amphibious movement, was a significant development during World War II. However, because of the nature of airborne operations, these were significantly dependent on a number of factors, i.e. trained and ready forces, sufficient troop carrier aircraft, and of course, suitable drop zones and the weather.

Terrain requirements for airborne drop zones were large, flat, open areas free of natural or human constructed obstacles (i.e. elements of the cultural landscape such as buildings). ${ }^{28}$ Because mass was one of the guiding principles, there was a desire to deliver the maximum number of paratroopers possible in the shortest time. Herrington notes, "As a yardstick, an area 1554,48 meter square (1 700 yard square) is ample for an airborne infantry battalion." ${ }^{29}$ It was also advisable to have a drop zone of sufficient size to discharge a stick of 21 paratroopers (the maximum number in a C-47 troop carrier plane) in one pass, precluding the need for an individual plane to make multiple passes over the same drop zone.

The two most important atmospheric factors affecting airborne operations are wind speed and cloud cover or ceiling, with wind playing a large role in determining the minimum drop zone size based on the number of paratroopers dropped in each pass. High wind speeds could also greatly disperse soldiers over larger areas as well as making consolidation of units on the drop zone significantly more challenging. Furthermore, high wind speeds significantly increase the likelihood of paratrooper casualties on landing. Although the author was unable to locate doctrinal requirements for these factors during the World War II time frame, cloud cover or low cloud ceiling would have prevented pilots from locating the drop zones correctly, while wind speeds less than 24,08 kilometres per hour $(\mathrm{km} / \mathrm{h})(13 \mathrm{knots})$ were considered safe for airborne operations. ${ }^{30}$

In terms of weather, US forces seemed to be in luck. Capt. Magnus Smith, an assistant regimental operations officer in the Rock Force, wrote, "February is the ideal time for military operations. During this month, a commander may expect light brief showers. In the early mornings a light mist will be present, but it will burn off by 0830." 31 More detailed climatological and meteorological data for the Philippines during the war was not found during the course of this research. However, data from Climate-Data.org (see Figure 6) provides a summary of climate data for Corregidor. ${ }^{32}$ This data, while not ideal as it was collected for the period 1982 to 2012, appears to reflect other commentary about the weather and climate patterns discussed in the historic literature. 
Corregidor is classified as an Aw: Tropical Savanna climate (by the Modified Köppen system) with a distinct dry winter, an average mean temperature of $26,1{ }^{\circ} \mathrm{C}$ $\left(79,0^{\circ} \mathrm{F}\right)$, and only 5,99 $\mathrm{mm}\left(0,236\right.$ inches) of rain in February. ${ }^{33}$ Additionally, as Capt. Mangus Smith noted in his monograph, the Northeast Monsoon weakens in late February, and winds average 24,08-31,48 km/h (13-17 knots) from the northeast, with potential gusts up to $40,74 \mathrm{~km} / \mathrm{h}$ (22 knots). ${ }^{34}$

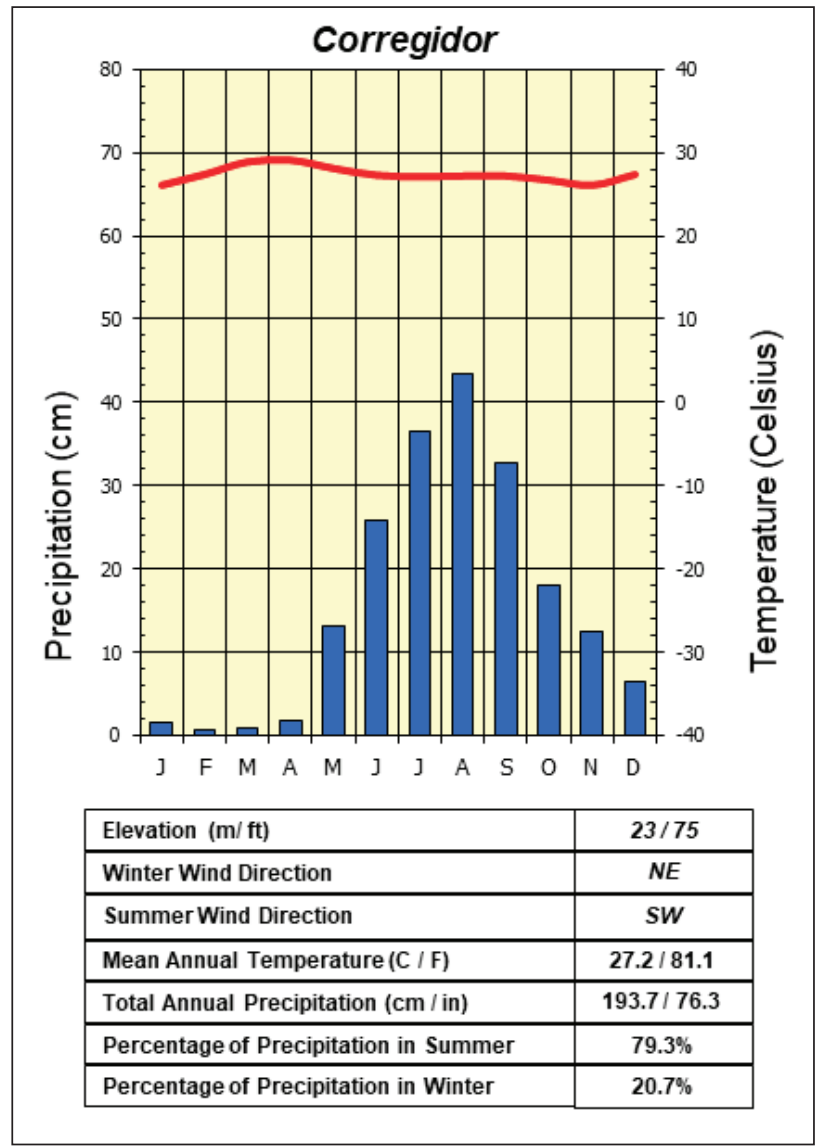

Figure 6: Climograph for Corregidor showing the average temperature and precipitation during the year. Although airborne forces can drop in the rain, increased precipitation is often accompanied by greater cloud cover, which could have significantly affected the operation if it was conducted during the wet season. February experiences the smallest amount of monthly rainfall. Constructed by author using data from Climte-Data.org. 
The expected wind speeds of 15-20 knots were not viewed as a significant factor that would have cancelled or postponed the operation. However, the actual wind speed was, at times, approximately 20 miles per hour (21.7 knots), which was five mph more than was considered safe for airborne operations at the time. Moreover, wind direction was more out of the north than expected. ${ }^{35}$ These factors, however, did have an effect as these higher wind speeds caused the first passes to be dispersed and blew a number of the paratroopers off the drop zone and over the cliff, to the narrow beaches as well as into the sea below. This error was also a result of the first pass dropping paratroopers between 550 and 600 feet above the drop zone, instead of the planned 400 feet drop altitude. Although several were lost, most were recovered by US patrol boats positioned off the shore of Corregidor for such contingencies. Col. Jones and the air transport commander flying overhead in a command plane, were able to call for subsequent passes to lower their drop altitude and delay the 'go' signal for an additional six seconds, so that the winds blowing from the north/northeast would not further affect the remaining drops.

While the weather seemed acceptable for an airborne operation, the main question of where to drop the paratroopers on the island remained. Yet, in their search to determine a suitable drop zone, the American forces had a distinct advantage in terms of their intelligence on the island.

\section{Terrain intelligence and finalising the plan}

Although our ability to collect, analyse and process geographic data about operational areas has expanded exponentially since 1945, the Rock Force did possess a tremendous amount of what Doyle and Bennett ${ }^{36}$ termed "terrain intelligence", the "databank of information available to commanders" to allow for thorough strategic and tactical assessments of the terrain. While this level of terrain intelligence certainly contributed to the success of this operation, this case study provided some excellent lessons that could help inform how commanders and staffs could use such intelligence to formulate operational plans.

As Col. Jones, commander of the Rock Force, and his staff developed their plan, they were afforded a tremendous amount of 'terrain intelligence' from various sources. Four enlisted soldiers and three officers who had been stationed on Corregidor before the war, including Major General (Maj Gen.) William Marquat, who left the island with Gen. MacArthur in 1942, were made available to the staffs planning the mission. ${ }^{37}$ As the United States also had air supremacy over the area, planners were provided with recent aerial photographs, and commanders and staff down to company level were allowed to go along on regular bombing missions to get a first-hand view of the island..$^{38}$ Additionally, the Sixth Army headquarters provided a detailed terrain model of the island (see Figure 7) to the unit, not only for commanders and staff to use for planning, but also for subordinate commanders to brief these units down to platoon level (the model was kept in a tent under guard to maintain operational security). ${ }^{39}$ 


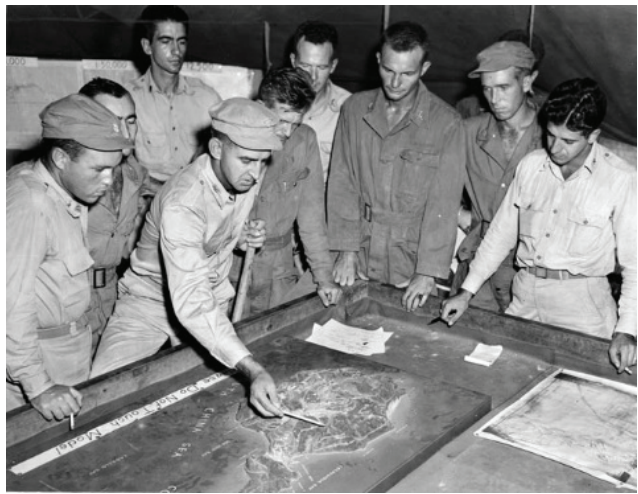

Figure 7: Col. George Jones, Commander, 503 ${ }^{\text {rd }}$ Parachute Regimental Combat Team, briefing his staff on the terrain model of Corregidor. ${ }^{40}$

As Capt. Levine wrote, "Corregidor lacked every desirable characteristic for a jump zone." ${ }^{\prime 41}$ It was small, with steep cliffs on the north, west, and south sides, and had virtually none of the attributes desired for a large-scale airborne operation. Upon initial inspection, it appeared the only suitable drop zone was Kindley Field, the landing strip constructed by the Americans before the war (marked 'Landin Field' in Figure 8). Although Japanese forces occupying Corregidor had not used the field, and it was significantly overgrown with vegetation, Col. Jones flew an aerial reconnaissance mission over the island during the planning stages, and concluded that Kindley field offered the best choice for a drop zone. However, his recommendation was disapproved by Gen. Krueger, who felt it "would not place the troopers on the key terrain feature quickly enough, and worse, the men landing on the airstrip would be subjected to the same plunging fire that troops making an amphibious assault would have to face". ${ }^{42}$ Additionally, the paratroopers dropped on the airfield would have to then fight uphill - twice - first up Malinta Hill, and then upwards from Bottomside to Topside on their drive to secure the critical 'head' of the island. ${ }^{43}$ Consequently, the decision was made to drop the troops onto Topside, They would then have the advantage of fighting downhill, rather than uphill. The two potential drop zones on Topside - the parade field and the golf course - however, were far from ideal.

As these plans were being developed, aerial bombardment of the island by B-24 Liberators armed with 226,8-kilogram (500-pound) bombs began on 23 January and continued for 25 days, with the final bombing run between 07:45 and 08:00 on 16 February. After 08:00, A-20s continued strafing runs on other parts of the islands, as well as neighbouring Caballo Island, to support the airborne and sea assaults while naval gunfire support from the Seventh US fleet fired in support of the amphibious assault by the $3 / 34^{\text {th }}$ Infantry, scheduled to land on the south shore at San Jose ${ }^{44}$ (see Figure 8). In the final version of the assault plan, there were three lifts of the $503^{\text {rd }}$ Parachute Regimental Combat Team on to the drop zones, beginning with the $3^{\text {rd }}$ Battalion and attached engineer and field artillery units at 08:30 on 16 February, 
followed by the second lift ( $2^{\text {nd }}$ Battalion) at 12:15 on 16 February, and the third ( $1^{\text {st }}$ Battalion) at $08: 30$ on 17 February. ${ }^{45}$ While this violated the principle of mass in airborne operations, it was the only feasible option based on the number of transport aircraft available and the size of the drop zones, ${ }^{46}$ to be discussed below. A coordinated amphibious assault by the $3^{\text {rd }}$ Battalion, 34 Infantry Regiment was planned for two hours after the first pass over the drop zone. By that time, the planners estimated the Japanese defenders would be fully focused on the fight at Topside while allowing the paratroopers enough time to secure positions from which they could establish support by fire positions to support the landing of the $3 / 34^{\text {th }} .{ }^{47}$

While the Americans benefitted from an exceptional level of terrain intelligence, which enabled their planning, intelligence on the enemy was lacking. Sixth Army intelligence officers estimated that there were no more than 850 Japanese defenders on Corregidor. However, once on the ground, the Rock Force found itself fighting against almost 6000 Japanese naval troops in its efforts to secure the island. ${ }^{48}$

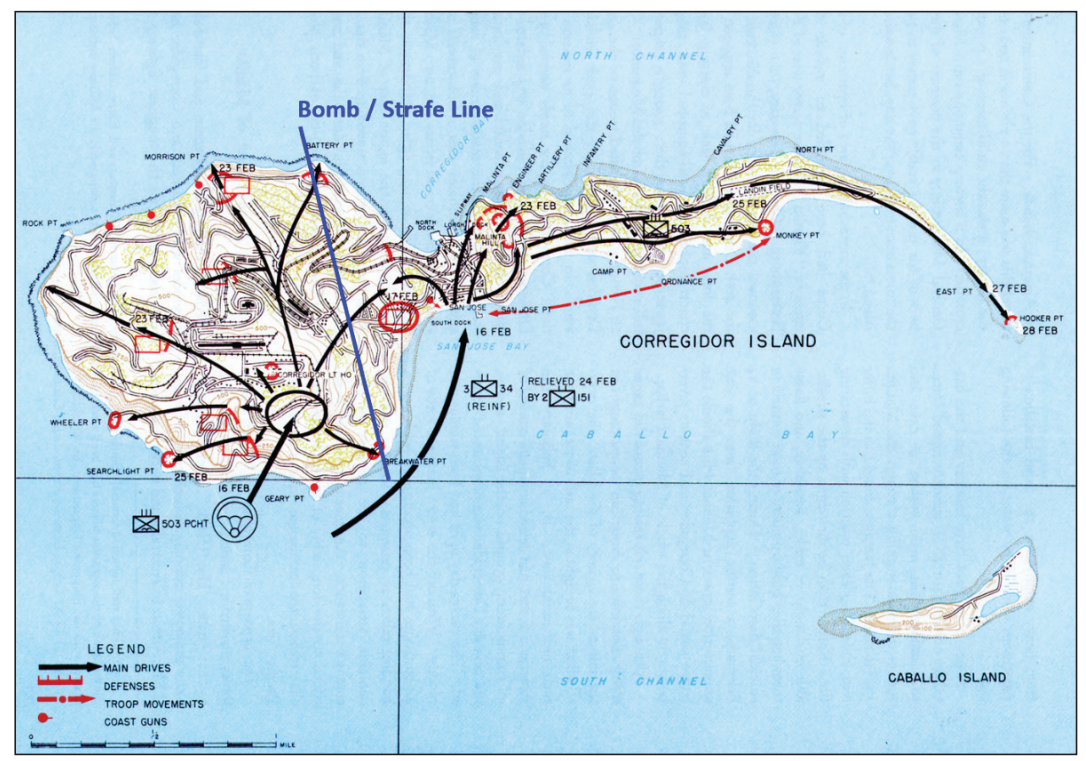

Figure 8: Map detailing the plan to assault Corregidor. The $503^{\text {rd }}$ Parachute Regimental Combat Team would parachute onto Topside, on drop zones A (parade ground) and B (golf course) starting at 08:30 on 16 February 1945 . Two hours after the start of that first drop, the $3 / 34^{\text {th }}$ Infantry (reinforced) would commence an amphibious landing on the south shore of Bottomside, on the beach adjacent to the village of San Jose. Once the airborne assault had begun, air and naval gunfire support shifted to east of the Strafe Line, from Breakwater Point to Battery Point. ${ }^{49}$ 


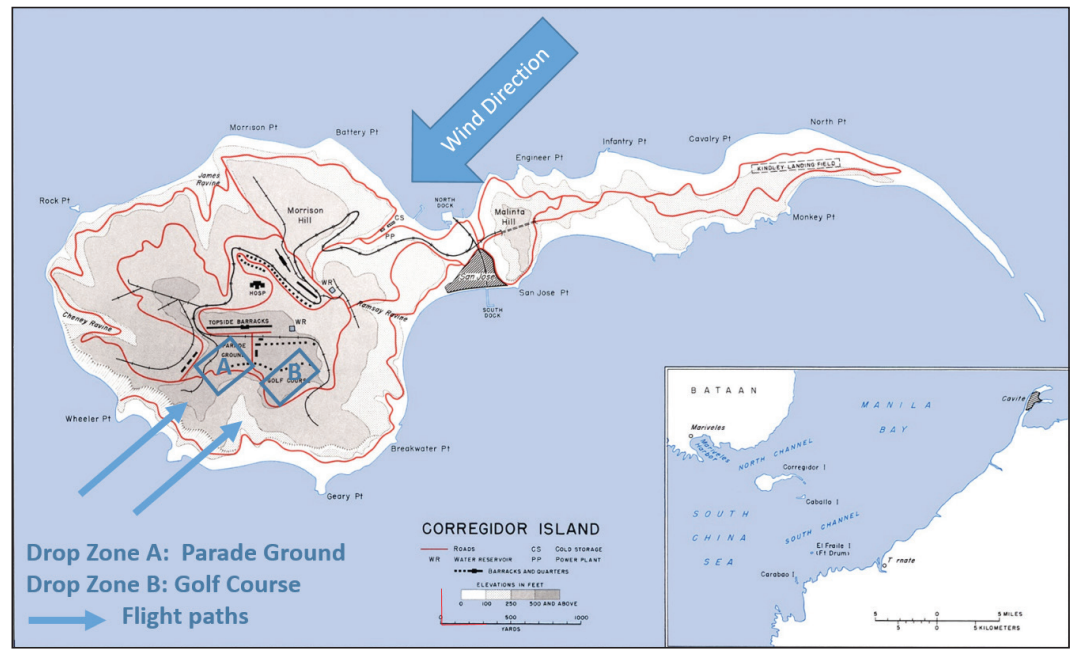

Figure 9: This map depicts the location of drop zones A (parade ground) and B (golf course), the prevailing wind pattern, and the approach flight routes for the $317^{\text {th }}$ Troop Carrier Group. ${ }^{50}$

\section{The cultural landscape: challenges and opportunities}

It seems somewhat ironic that spaces organised for pre-war training and recreation had to be the locations selected to conduct the airborne assault to recapture Corregidor. These locations were significant during the pre-war years. The parade ground was used for formations, training, physical exercise, and other functions. The golf course provided a recreational outlet that was enjoyed across many Army posts. These drop zones were, however, the only relatively flat, open areas suitable for an airborne drop. Soldiers who used both spaces prior to the war could not have foretold that these two features of the cultural landscape would play such a vital role in 1945 . Once decided, planners' understanding of the wind patterns allowed them to plan the approach flight for the drop (see Figure 9 and 10). 


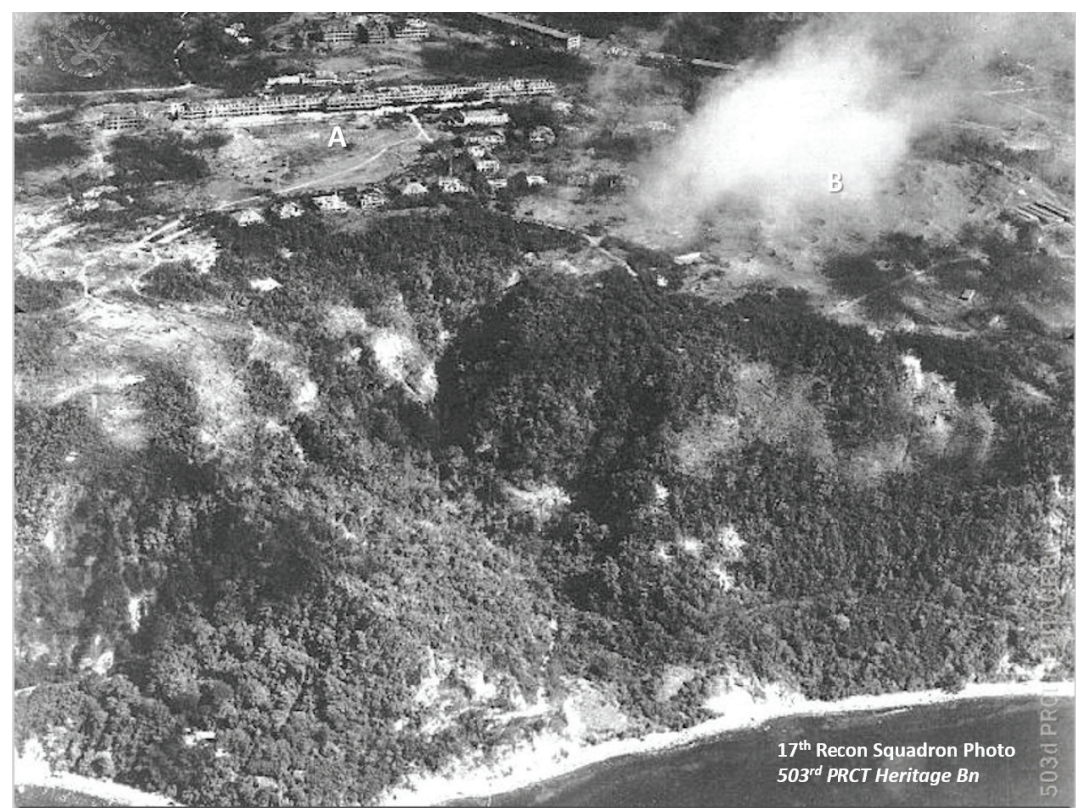

Figure 10: Aerial photo taken by the $17^{\text {th }}$ Recon Squadron showing the locations of drop zone A (parade ground in front of the long barracks) and drop zone B (golf course - under cloud). Note the precipitous slopes on the south edges of these drop zones, as well as the remnants of the barracks and other buildings on the edges of these drop zones. ${ }^{51}$

The airborne lifts, therefore, planned to drop one battalion task force onto the two drop zones at a time, and the biggest challenge of using the parade ground and the golf course was their size. Because of the small size of the drop zones, only six to eight paratroopers could exit the aircraft in a pass, which required the planes to drop their first pass, then circle around for a second and third pass to drop each stick. In the primary and secondary sources, there appears to be little consensus on the actual size of these spaces. Table 1 illustrates the size of each drop found within various sources. Different sources used either feet or yards, so these were converted (in red) to show equivalencies. As photographs of the drop zones show (Figure 10 and 11), the edges are not clearly defined and therefore subject to some interpretation. Considering the $317^{\text {th }}$ Troop Carrier Group was the air unit assigned to deliver the $503^{\text {rd }}$ Parachute Infantry onto the drop zones and likely had the best access to aerial reconnaissance and photography, the size estimates of those sources appear the most likely approximation. The real value of this data confirms that these two drop zones were significantly smaller than that desired for an infantry battalion. 
Table 1: Comparison of the sizes of the drop zones in various sources.

\begin{tabular}{|c|c|c|c|c|}
\hline & \multicolumn{2}{|c|}{ DZ A: Parade Field } & \multicolumn{2}{|c|}{ DZ B: Golf Course } \\
\hline & Length & Width & Length & Width \\
\hline 317th Troop Carrier Group & 500 yds & $67-233$ yds & 500 yds & $150-233$ yds \\
\hline Primary source, 1945 & $1500 \mathrm{ft}$ & $200-700 \mathrm{ft}$ & $1500 \mathrm{ft}$ & $450-700 \mathrm{ft}$ \\
\hline Blair & $250 \mathrm{yds}$ & $150 \mathrm{yds}$ & 300 yds & $150 \mathrm{yds}$ \\
\hline Primary source, 1950 & $750 \mathrm{ft}$ & $450 \mathrm{ft}$ & $900 \mathrm{ft}$ & $450 \mathrm{ft}$ \\
\hline Flash & 250 yds & 150 yds & 300 yds & $150 \mathrm{yds}$ \\
\hline Primary source, 1950 & $750 \mathrm{ft}$ & $450 \mathrm{ft}$ & $900 \mathrm{ft}$ & $450 \mathrm{ft}$ \\
\hline Caskey & $150 \mathrm{yds}$ & 100 yds & 250 yds & 150 yds \\
\hline Primary source, 1949 & $450 \mathrm{ft}$ & $300 \mathrm{ft}$ & $750 \mathrm{ft}$ & $450 \mathrm{ft}$ \\
\hline Smith, Magnus & $350 \mathrm{yds}$ & & 325 yds & \\
\hline Primary source, 1950 & $1050 \mathrm{ft}$ & & $975 \mathrm{ft}$ & \\
\hline Bush, et al & $460 \mathrm{~m}$ & $60-210 m$ & $460 \mathrm{~m}$ & $140-210 \mathrm{~m}$ \\
\hline Secondary source, 1983 & $1509 \mathrm{ft}$ & $197-689 \mathrm{ft}$ & $1509 \mathrm{ft}$ & $460-689 \mathrm{ft}$ \\
\hline Devlin & 325 yards & 250 yards & 350 yds & $185 \mathrm{yds}$ \\
\hline Secondary source, 1979 & $975 \mathrm{ft}$ & $750 \mathrm{ft}$ & $1,050 \mathrm{ft}$ & $555 \mathrm{ft}$ \\
\hline Jenkins & 500 yds & $150 \mathrm{yds}$ & $500 \mathrm{yds}$ & $67-150$ yds \\
\hline Secondary source, 1946 & $1500 \mathrm{ft}$ & $450 \mathrm{ft}$ & $1500 \mathrm{ft}$ & $200-450 \mathrm{ft}$ \\
\hline Murdock & 325 yds & 250 yds & 350 yds & 180 yds \\
\hline Secondary source, 1991 & $975 \mathrm{ft}$ & $750 \mathrm{ft}$ & $1,050 \mathrm{ft}$ & $555 \mathrm{ft}$ \\
\hline Rottman & 325 yds & 250 yds & 350 yds & 180 yds \\
\hline Secondary source, 2007 & $975 \mathrm{ft}$ & $750 \mathrm{ft}$ & $1,050 \mathrm{ft}$ & $555 \mathrm{ft}$ \\
\hline \multicolumn{5}{|c|}{ Numbers in Black: as listed in document } \\
\hline \multicolumn{5}{|c|}{ Red numbers: converted to other measurment } \\
\hline
\end{tabular}




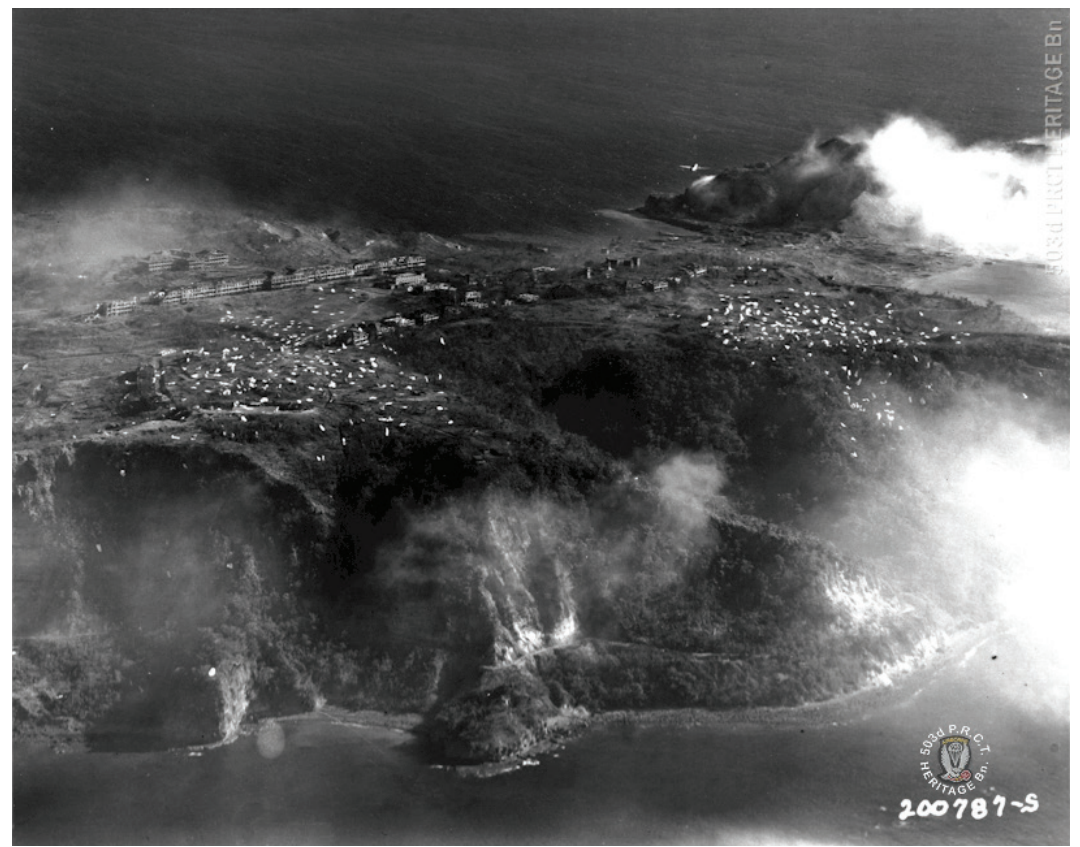

Figure 11: This image shows the steep cliffs on the southwest side of Corregidor with drop zone A (parade field) on the left and drop one B (golf course) on the right. Notice the parachutes on the edge and down the cliffs. ${ }^{52}$

While the parade ground and golf course provided the necessary (but exceptionally small) spaces needed for drop zones, the other elements of the cultural landscape proved to offer both challenges and advantages for the paratroopers. One issue that confronted the airborne forces was the remnants of the other features of the cultural landscape (buildings) along the edges of these open spaces (see Figure 12). While these buildings posed significant obstacles to the paratroopers under normal conditions, the results of this bombing, while serving to soften the target prior to the assault, added to the difficulty of these locations as drop zones (see Figure 12). Crawford, in his monograph of the operation states:

The entire island is guttered with deep ravines with precipitous sides. The aerial bombardment had stripped the trees of any foliage and splintered and shattered the trunks until they created a parachute hazard. The bombing had also wrecked the buildings. The barracks buildings were of the three story reinforced concrete type and, after bombing, created still another parachute hazard. The fields selected for the drop abounded in bomb craters, huge boulders, and large sunbaked clods of clay which were almost like rock themselves. The cliffs facing the beach, sides of the ravines and the old gun batteries had been made into well-fortified positions. ${ }^{53}$ 


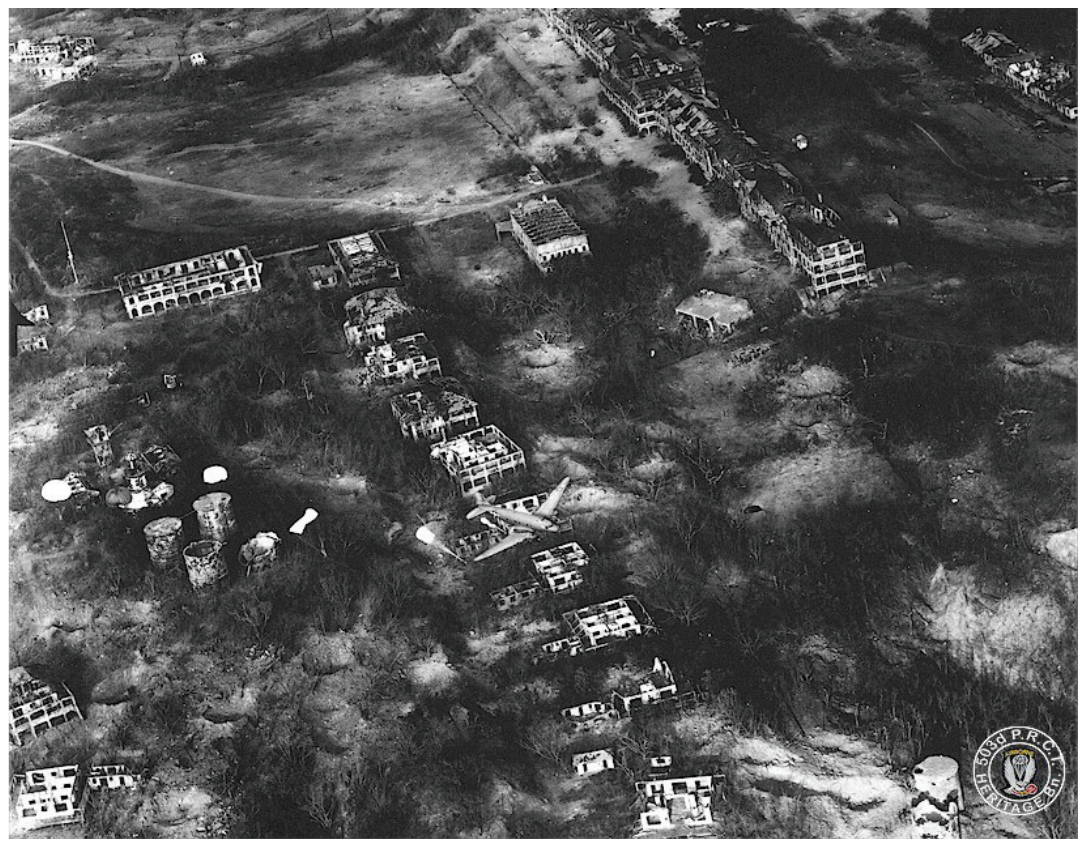

Figure 12: "At 0830 hours, with the first parachutes yet to land, a C-47 passes over Officers Row and drops on Landing Zone B. There are 7 chutes pictured. The 25 knot wind really blew us back. Between the Ciné and Mile Long Barracks, on an angle, is the telephone exchange building - it's early seizure will shatter all organised Japanese communication throughout the island." 54

Levine comments on the 'hazards' these bombed buildings and debris posed also noted that they created arguably the most dangerous drop zone of any in World War II. While the planners expected jump casualty rates of $20 \%$, Col. Jones thought they could run as high as $50 \%$, based on the small size of the drop zones and debris and ruined structures around them. ${ }^{55}$ However, planners estimated jump casualties would still be below those of a solely amphibious assault. Fortunately, for the $503^{\text {rd }}$, these estimates proved wrong; nevertheless, the unit did suffer the highest jump casualty rate of any airborne operation in the war. ${ }^{56}$

A report prepared for the adjutant general on the operation to highlight lessons learned for future airborne planning and operations listed the actual casualty rates during the entire operation at $10,7 \%$, but also noted that "of the total number of men who dropped over the cliffs, nine made their way to the beach and were taken off by naval craft, making the actual loss on the jump 11,2\%," - higher than any other US airborne operation in the war, but still $9 \%$ lower than the pre-assault estimate. ${ }^{57}$ 
Table 2: American casualties during the Corregidor operation. ${ }^{58}$

\begin{tabular}{|l|l|}
\hline Total number of jumpers & 2065 \\
\hline Injured on landing & 203 \\
\hline Killed: chute malfunction & 3 \\
\hline Killed: striking buildings & 2 \\
\hline Killed in action (KIA) by enemy prior to or on landing & 0 \\
\hline Missing & 14 \\
\hline Actual casualties: & 222 \\
\hline Over the cliff but recovered & 9 \\
\hline Jump casualty rate & $11,2 \%$ \\
\hline
\end{tabular}

Closer examination of these casualties revealed that $75 \%$ of all jump casualties were sustained during the first drop, but that there were no serious wounds (from enemy fire) received prior to landing. Once the first lift began dropping their troops, Col. Jones, flying over the island in a command plane, was able to make adjustments to the drop altitude and 'go' point for each stick to start the jump, which undoubtedly reduced the number of potential jump casualties. Of the 203 jumpers injured on landing, 180 had to be evacuated and "twenty odd of the men incurring injuries from the jump stayed in action for a day or more before being hospitalized". ${ }^{59}$ Comparing the jump casualties (222 paratroopers) with the total killed, wounded, injured and sick, $26,6 \%$ of the casualties of $503^{\text {rd }}$ PRCT resulted from the airborne drop.

Table 3: Total number of casualties by type suffered by US forces during the Corregidor operation. Jump casualties are not listed separately. ${ }^{60}$

\begin{tabular}{|l|c|c|c|c|c|c|c|c|c|}
\hline & \multicolumn{2}{|c|}{ KIA\&DOW } & \multicolumn{2}{c|}{ WOUNDED } & \multicolumn{2}{c|}{ SICK } & \multicolumn{2}{c|}{ INJURED } & TOTAL \\
\cline { 2 - 10 } & O & EM & O & EM & O & EM & O & EM & \\
\hline $\begin{array}{l}503 d \\
\text { RCT }\end{array}$ & 17 & 148 & 17 & 267 & 7 & 57 & 15 & 316 & 841 \\
\hline $\begin{array}{l}\text { Other } \\
\text { Units }\end{array}$ & 1 & 44 & 5 & 158 & 1 & 44 & 0 & 8 & 264 \\
\hline Totals & 18 & 192 & 22 & 425 & 8 & 101 & 15 & 324 & 1105 \\
\hline
\end{tabular}

Aside from the jump casualties, the first lift of the $503^{\text {rd }}$ faced little opposition initially. As many official history reports and first-hand accounts noted, the Japanese appeared to be completely surprised by the airborne assault and Topside was defended by "only a few small groups of Japanese armed with light machines guns and rifles". ${ }^{61}$ By the time they did start to react, many of the first passes were safely on the ground and working to suppress Japanese defensive positions. Smith noted that several officers in the first lift attempted to call for cancelling the second lift because of the hazardous conditions, but because of communications issues, the second lift proceeded as planned, dropping the first of its three passes over the drop zone at $12: 40,25$ minutes later than planned. ${ }^{62}$ 
While the second lift sustained fewer jump casualties, because of the adjustments made from the first, more paratroopers were shot while in the air or upon landing. However, post-action reports did not reveal how many were included in these categories. Although jump casualty rates were lower for the second lift, and the two battalions (first two lifts) were securing control of Topside, Col. Jones cancelled the third lift ( $1^{\text {st }}$ Battalion) scheduled for 08:30 on the second day, 17 February. This force was flown via the transports to Luzon, trucked to Mariveles, and then transported to the island via landing craft for a landing on the beach secured by the $3 / 34^{\text {th }}$ Infantry.

The conditions in and around the drop then, were severely hazardous. Shattered buildings, debris, craters and splintered trees proved treacherous to many of the soldiers landing on or near the drop zones. One soldier, who experienced a parachute malfunction, landed in a swimming pool that was empty and unused during the time of the attack. Capt. Henry Hill, commander of E Company, 2/503 $3^{\text {rd }}$, landed on the top of a three-storey building, upon which his chute collapsed and he "tumbled through the ruins to the ground floor", his only "injury seven teeth knocked out or broken off'" ${ }^{63}$ For him, though, this proved fortunate as the enemy machine gun positions were sweeping the area around the building and the drop zone with intense fire.

Although the remnants of the cultural landscape (buildings) proved hazardous during the jump, these same features provided cover and protection for the forces once on the ground. In that same building, Capt. Hill found around fifty men from E and F companies trapped inside because of enemy fire. Additionally, an inherent challenge during airborne operations is the ability for paratroopers to quickly form into their coherent units once on the ground. To enable this, these designated assembly locations must be clearly identifiable and easily recognisable. The assembly area for Hill's company was the west end of the Long Barracks, north of the parade field drop zone. However, he could not reach this location because of enemy fire. Once the Japanese position pinning him down was reduced, he found his company executive officer, Lt Donald Abbott, at the assembly point with approximately sixty men. Such locations made it relatively easy for paratroopers to find their assembly points, although as Hill's case demonstrates, not always easy to reach.

This barracks, the longest in the world at the time, lay in ruins, but like the other remaining structures, offered protection and cover for the airborne forces to consolidate and organise their efforts to clear Topside (see Figure 13). This feature of the cultural landscape was close to the drop zones and ultimately served as the Rock Force Command Post and Regimental Combat Team headquarters, the $462^{\text {nd }}$ Field Artillery Battalion Command Post and Fire Direction Center, the $161^{\text {st }}$ Engineer Company Command Post as well as other attached assets such as the Joint Assault Signal Company and Support Air Party headquarters, and the force's medical detachments, which established their casualty collection point and field hospital in the ruins. 


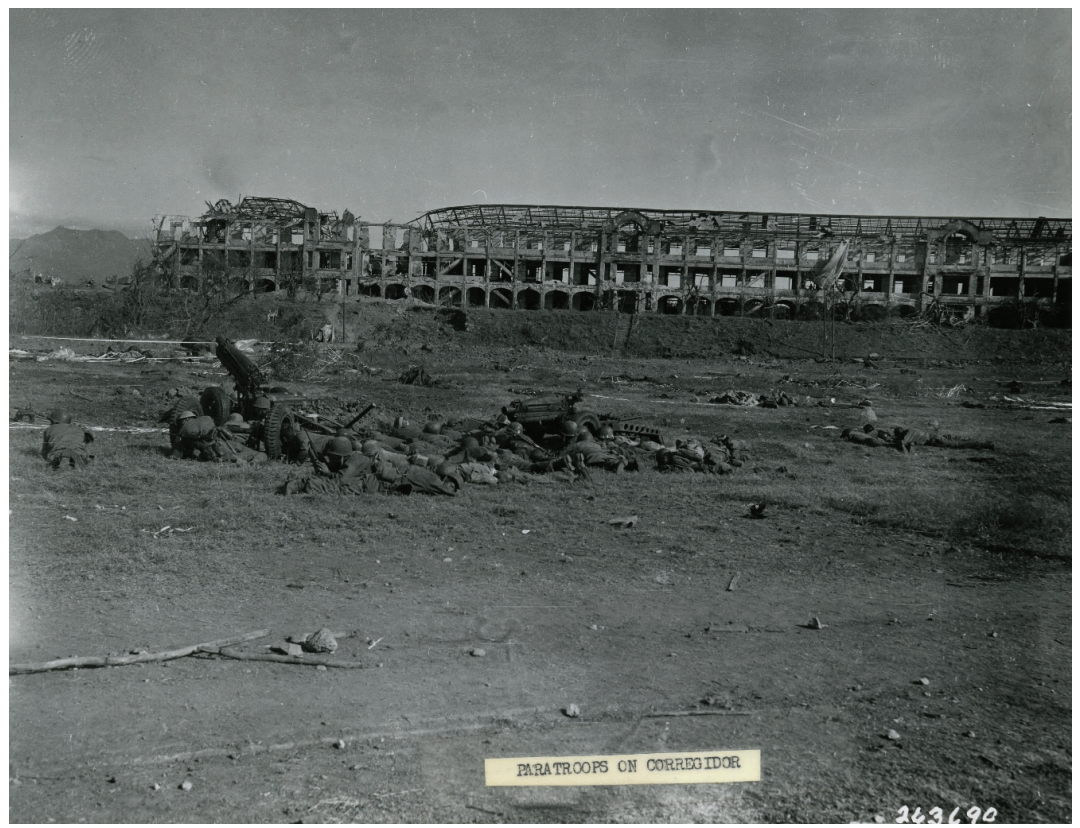

Figure 13: A $75 \mathrm{~mm}$ artillery piece of the $462^{\text {nd }}$ Field Artillery Battalion on drop zone A (parade field) with the remnants of the Long Barracks in the background. US Army Signal Corps photo. ${ }^{64}$

Although the first lift of the airborne operation caught the Japanese defenders off guard and achieved surprise, this did not last long. The operation ultimately took from 16 February until 2 March - a period of incredibly hard fighting to declare the island secure. Throughout this battle, the cultural landscape played a pivotal role, not only during the planning and initial airborne drop, but also in the subsequent fight to secure control over key features of Corregidor's landscape.

\section{Conclusion}

Although there were strategic reasons that led to the American assault on Corregidor (to eliminate Japanese abilities to interdict Allied shipping into Manila Bay), there were also symbolic motivations as well. As Flanagan noted, "[its] capture would erase from the minds of the American people the dark memories of 1942 - the tortured prisoners and the ignominy of Wainwright's surrender - and these were the inspirational reasons for taking Corregidor". ${ }^{65}$ And as Gen. MacArthur proclaimed, "History, I am sure will record it as one of the decisive battles of the world ... Let no man henceforth speak of it other than a magnificent victory." ${ }_{66}$ Clearly, these symbolic objectives were as important as the strategic considerations. Moreover, these objectives aside, the American assault on Corregidor highlights many parallels to conflict today. 
As this research demonstrates, the 1945 battle to recapture Corregidor Island is an excellent case study of military geography, not only from an historical perspective, but also for its similarities to the current operating environment. This analysis demonstrates that while the physical terrain of Corregidor was challenging and weather was a vital consideration, the cultural landscape proved far more significant in the planning and the subsequent course of the battle. Without those two small spaces, developed for pre-war training and recreation activities, an airborne assault on to Topside was not possible. As a result, an airborne assault on Kindly field on the tail of the island or an entirely amphibious assault would have played directly into the Japanese defensive plan, with potentially much larger US casualties. Although the small size of these drop zones and the gutted buildings and debris from the pre-assault bombardment resulted in the highest jump casualties of the war, these same features likely saved American lives, providing cover and protection against Japanese fire once the paratroopers had landed.

While modern technology has enabled military forces to overcome many challenges of geography, Flanagan's analysis, although focused on the specifics of the battle of Corregidor, offers sage advice for military planners and commanders applicable to today: "The successful commander is the one who studies the situation, assesses his forces and the enemy, analyzes the terrain, considers the weather, and the weighs all of the factors and makes a decision." ${ }^{97}$ The intent of this analysis was to broaden traditional conceptions of terrain and illuminate the potential effects of cultural landscapes in war. In today's much more populated world, with ever more ways humans modify the natural landscape, military operations are increasingly affected by the cultural landscape, which could pose unique challenges and opportunities. Analysing historical examples of such effects can provide valuable insights into the present and the future on how these cultural landscapes may influence military operations.

\section{Endnotes}

${ }^{1}$ G Cromley. "Designing a military event gazetteer: The case of parachute operations during the French Indochina War". The Professional Geographer. 68/2. 2016. 249-260.

${ }^{2}$ 503d PRCT Heritage Battalion. < http://corregidor.org/heritage_battalion/index. htm>

${ }^{3}$ EM Flanagan. Corregidor, the Rock Force Assault, 1945. Novato, CA: Presidio, 1988.

${ }^{4} \mathrm{H}$ Winters. Battling the elements: Weather and terrain in the conduct of war. Baltimore, MD: Johns Hopkins University Press, 1998.

${ }^{5}$ JE Bush, WM Cochrane, JR Gingrich, DF Gross, CD Hackett \& DP Schultz. Corregidor-February 1945: A battlebook presented to the staff and faculty of the United States Army Command and General Staff College. Fort Leavenworth, KS: US Army Command and General Staff College, 1983. ii. 
${ }^{6}$ Flanagan op. cit., p. 23.

${ }^{7}$ WD Smith. "The geology of Luzon, P.I.". The Journal of Geology 21/1. Jan-Dec 1913. 29-61.

${ }^{8}$ G Rottman. World War II Pacific Island guide: A geo-military study. Westport, CT: Greenwood Press, 2002.

${ }^{9}$ Retrieved from The MacArthur memorial. http://www.macarthurmemorial.org/171/ Corregidor---Philippine-Campaign-1945

${ }^{10}$ Flanagan op. cit.; MA Berhow \& T McGovern. American defenses of Corregidor and Manila Bay 1898-1945. Oxford: Osprey, 2003.

${ }^{11}$ Rottman op. cit.

${ }^{12}$ Smith op. cit.

${ }^{13} \mathrm{JH}$ Belote \& WM Belote. Corregidor: The stirring saga of a mighty fortress. New York, NY: Playboy Paperbacks, 1980. 20.

${ }^{14}$ Map VII: Corregidor Island, in Smith, Robert. 1993. Triumph in the Philippines. Center for Military History.

${ }^{15}$ AJ Aluit. The Galleon history of Corregidor. Manila: Galleon. 1968., p6.

${ }^{16}$ Berhow \& McGovern op. cit.

${ }^{17}$ Ibid.

${ }^{18}$ Ibid.

${ }^{19}$ Colonel William Alfonte Collection, MacArthurmemorial.org.

${ }^{20}$ L Morton. The fall of the Philippines. Washington, DC: Office of the Chief of Military History, Department of the Army, 1953.

${ }^{21}$ RR Smith. Triumph in the Philippines. Washington, DC: United States Army Center of Military History, 1993.

${ }^{22}$ Ibid., pp. 8-9.

${ }^{23}$ Ibid.; LH Levine. The operations of the 503 ${ }^{\text {rd }}$ Parachute Infantry Regiment in the attack on Corregidor Island, 16 February - 2 March 1945: Personal experience of a regimental adjutant. Advanced Infantry Officers Course 19471948. Fort Benning, GA, 1948.

${ }^{24}$ RR Smith op. cit., p. 339.

${ }^{25}$ Levine op. cit., p. 12.

${ }^{26} \mathrm{G}$ Rottman. US airborne units in the Pacific theater 1942-45. Oxford: Osprey, 2013.

${ }^{27} \mathrm{JW}$ Herrington. "Planning an airborne assault". Military Review. 31/11. 1952. 35-47; Bush et al. op. cit.

${ }^{28}$ Heffington op. cit.; Bush et al. op. cit.

${ }^{29}$ Heffington op. cit., p. 37.

${ }^{30}$ RR Smith op. cit., p. 343.

${ }^{31}$ M Smith. Operations of the "Rock Force" (503D RCT Reinforced) in the recapture of Corregidor Island, 16 February - 8 March 1945 (Luzon Campaign): Personal experience of an assistant regimental operations officer. Advanced Infantry Officers Course 1949-1950. Fort Benning, GA, 1950. 5.

${ }^{32}$ Climate-Data.org. <https://en.climate-data.org/location/495056/>. 
${ }^{33}$ W Köppen. 'Das Geographische System der Klimate', in Köppen, W. and Geiger, R. (eds.), Handbuch der Klimatologie, Vol. I, Part C, Gebrüder Borntraeger, Berlin. 1936.

${ }^{34} \mathrm{M}$ Smith op. cit.

${ }^{35}$ RR Smith op. cit., pp. 343-344.

${ }^{36}$ P Doyle \& MR Bennett. Fields of battle: Terrain in military history. Boston, MA:

Kluwer Academic, 2002. 3.

${ }^{37} \mathrm{M}$ Smith op. cit.

${ }^{38}$ Ibid., p. 13.

${ }^{39}$ Levine op. cit., p. 19.

${ }^{40}$ National Archives.

${ }^{41}$ Ibid., p. 13.

${ }^{42}$ RR Smith op. cit., p. 337.

${ }^{43}$ Ibid.; Levine op. cit.

${ }^{44}$ Levine op. cit., p. 24.

${ }^{45}$ D Crawford. Operations of the 503D Parachute Regimental Combat Team in capture of Corregidor Island, 16 February - 2 March 1945: Personal experience of a regimental assistant S-1. Advanced Infantry Officers Course 1948-1949. Fort Benning, GA, 1949. 13., p. 18.

${ }^{46}$ Flanagan op. cit.

${ }^{47}$ R Smith op. cit., p. 339.

${ }^{48}$ Ibid.; Belote \& Belote op. cit.

${ }^{49}$ PLATE NO. 80: Recapture of Corregidor, 16-28 February 1945, Reports of General MacArthur. 1966.

${ }^{50}$ Map VII: Corregidor Island, in Smith, Robert. 1993. Triumph in the Philippines. Center for Military History.

${ }^{51}$ Photo retrieved from the $503^{\text {rd }}$ PRCT Heritage Battalion webpage.

${ }^{52}$ US Army Signal Corps photo. Retrieved from the 503 ${ }^{\text {rd }}$ PRCT Heritage Battalion webpage.

${ }^{53} \mathrm{D}$ Crawford. op. cit. 13.

${ }^{54} 17$ th Recon Squadron, Army Air Corps. Retrieved from the 503 ${ }^{\text {rd }}$ PRCT Heritage Battalion webpage.

${ }^{55}$ RR Smith op. cit.

${ }^{56}$ Heffington op. cit.

${ }^{57}$ USAFFE. "Report no. 309. Corregidor Island Operation". Headquarters, United States Army in the Far East. 16 May 1945. < http://corregidor.org/BEA503/

Reports/Corregidor/usaffe_board_report_01.html $>$ Accessed on 15 January 2018, 2.

${ }^{58}$ USAFFE Report 309, dated 16 May 1945.

${ }^{59} \mathrm{Ibid}$.

${ }^{60}$ USAFFE Report 309, 16 May 1945.

${ }^{61}$ RR Smith op. cit., p. 341.

${ }^{62}$ Ibid., p. 344. 
${ }^{63} \mathrm{H}$ Hill. The operations of Company “E”, 503D Parachute Regiment at Wheeler Point, Island of Corregidor, Philippine Islands 23 February, 1945 (Luzon Campaign): Personal experience of a company commander. Advanced Infantry Officers Course 1947-1948. Fort Benning, GA, 1948. 6.

${ }^{64}$ Retrieved from United States Military Academy Archives.

${ }^{65}$ Flanagan op. cit., p. 164.

${ }^{66}$ D MacArthur. Reminiscences. New York, NY: McGraw Hill, 1964. 250.

${ }^{67}$ Flanagan op. cit., p. xiv. 